Jurnal Pembangunan Wilayah dan Kota

Vol.15, No.4, 2019, 275-287

P-ISSN: 1858-3903 and E-ISSN: 2597-9272 https://ejournal.undip.ac.id/index.php/pwk/index

\title{
ANALISIS SUMBERDAYA WILAYAH UNTUK PENGEMBANGAN INDUSTRI DI PROVINSI NUSA TENGGARA BARAT
}

\section{REGIONAL RESOURCES ANALYSIS FOR INDUSTRIAL DEVELOPMENT IN THE WEST NUSA TENGGARA PROVINCE}

\author{
Joni Purwohandoyo a, Bobby Tumpal Lubis ${ }^{b}$, Yustikarani Julianti Pambudic, Muhammad Sidiq Wicaksonod
}

1 Fakultas Geografi UGM; Bulaksumur, Yogyakarta, 55281; Jonipurwo@ugm.ac.id, joni_4778@yahoo.com

2 Dinas Pekerjaan Umum, Perumahan dan Energi Sumberdaya Mineral Provinsi DIY; Jl. Bumijo No. 5, Yogyakarta, 55281; bo loebis@yahoo.com

3 Magister Manajemen Fakultas Ekonomika dan Bisnis UGM; Bulaksumur, Yogyakarta, 55281; yustikarani.j.pambudi@gmail.com

4 Sekolah Vokasi UGM; Bulaksumur, Yogyakarta, 55281; sidiqwicaksono@gmail.com

Info Artikel:

- Artikel Masuk: 14 Januari 2019 - Artikel diterima: 22 November 2019 - Tersedia Online: 31 Desember 2019

\begin{abstract}
ABSTRAK
Provinsi Nusa Tenggara Barat merupakan salah satu provinsi di Indonesia yang menaruh perhatian khusus terhadap pengembangan industri. Sumberdaya wilayah menjadi faktor penentu dalam pengembangan industri, yang terdiri dari sumberdaya alam dan sumberdaya manusia. Sumberdaya wilayah dan didukung dengan prasyarat industri terkait dengan kebijakan pemerintah akan menentukan sektor industri unggulan dan strategi pengembangan industrinya. Penelitian ini menggunakan pendekatan kuantitatif dan kualitatif. Untuk melihat konsentrasi sumberdaya alam di Provinsi NTB menggunakan analisis LQ sedangkan penentuan industri unggulan menggunakan analisis kesenjangan. Berdasarkan hasil analisis terdapat dua jenis industri yang menjadi unggulan di Provinsi NTB yaitu agroindustri dan industri kerajinan. Kedua jenis industri ini merupakan industri dengan tingkat kesenjangan yang rendah. Strategi pengembangan industri di Provinsi NTB disesuaikan dengan kondisi masing-masing jenis industri.
\end{abstract}

Kata kunci : Sumberdaya Wilayah; Industri; Strategi Pengembangan

\section{ABSTRACT}

West Nusa Tenggara Province is one of the province in Indonesia that put special attention on industrial development. The existed resources of the region is one of the determinant factor in developing industry that consists of natural resources and human resources. Region resources which is supported with industrial prerequisite related with government policy will determine superior industrial sector and its development strategy. This research use quantitative and qualitative method. To understand the natural resources concentration in West Nusa Tenggara Province, the analysis method used is LQ analysis. While superior industry determination use gap analysis. According to the analysis result, there are two industry that become superior in West Nusa Tenggara Province, namely agroindustry and handcraft industry. Both of this industry has low rate of gap. Development strategy of industry in West Nusa Tenggara is adjusted with condition of each industry.

Keywords: Regional Resources; Industry; Development Strategy 
Purwohandoyo, Lubis, Pambudi, Wicaksono/ Jurnal Pembangunan Wilayah dan Kota, Vol.15, No.2, 2019, 275-287

Doi: https://doi.org/10.14710/pwk.v15i4.21732

\section{PENDAHULUAN}

Industri merupakan bagian penting dari sektor ekonomi. Kegiatan utama pada sektor ini adalah mengolah bahan mentah atau bahan baku menjadi barang setengah jadi dan barang jadi sehingga memiliki nilai tambah yang lebih (Dumairy, 1996 dan Kartasapoetra, 2000). Menurut Undang-Undang Nomor 3 Tahun 2014 tentang Perindustrian, industri adalah seluruh bentuk kegiatan ekonomi yang mengolah bahan baku dan/atau memanfaatkan sumberdaya industri sehingga menghasilkan barang yang mempunyai nilai tambah atau manfaat lebih tinggi, termasuk jasa industri. Berdasarkan kedua pengertian tersebut, konsep utama dalam industri mencakup 2 (dua) hal penting yaitu proses pengolahan dan penciptaan nilai tambah yang lebih tinggi. Keduanya memberikan makna bahwa sektor industri merupakan salah satu sektor penting dalam meningkatkan perekonomian baik daerah maupun nasional.

Peningkatan perekonomian baik daerah maupun nasional dapat dipicu melalui aktivitas ekonomi yang mampu memberikan dampak signifikan salah satunya melalui sektorinddustri. Singgih dan Hennytasari (2009) menyatakan bahwa sektor industri merupakan sektor yang mempunyai pengaruh besar terhadap perekonomian dan lingkungan. Pengaruh industri memberikan dampak positif bagi daerah sekitarnya seperti adanya multiplier effect. Dampak ini berupa munculnya berbagai kegiatan ekonomi baru yang menjadi sarana penyerapan tenaga kerja (Wulandari, 2007).

Penyerapan tenaga kerja dapat terjadi pada penduduk baik yang bekerja di sektor pertanian maupun non pertanian. Penduduk yang bekerja pada sektor pertanian dapat meningkatkan pendapatan dan kesejahteraannya dengan bekerja juga di sektor industri (Nawawi et al. 2015). Selain aspek tenaga kerja, integrasi sektor pertanian dan industri ini juga dapat menciptakan nilai tambah pada produk atau hasil-hasil pertanian. Hal ini juga akan memicu peningkatan "nilai tukar " petani terhadap sektor ekonomi lainnya. Dengan demikian sektor pertanian pada gilirannya dapat berkembang karena hasil produksi pertanian dapat diolah dan memberikan nilai tambah yang lebih tinggi.

Pemberian nilai tambah dari hasil industri menjadi lebih optimal melalui pengembangan industri kreatif. Industri kreatif menurut Departemen Perdagangan Republik Indonesia (2008) adalah pemanfaatan kreativitas, keterampilan, serta bakat individu untuk menciptakan kesejahteraan serta lapangan pekerjaan untuk masyarakat melalui penciptaan dan pemanfaatan daya kreasi dan daya cipta individu tersebut. Industri kreatif merupakan proses pengolahan bahan baku secara kreatif yang memiliki ciri khas produk komersial yang memiliki kandungan estetika dan simbolik yang tinggi (Scott, 2000). Berdasarkan pengertian ini maka industri kreatif merupakan pemberian nilai tambah lebih pada produk hasil industri dengan menggunakan kreativitas, keahlian serta bakat individu.

Provinsi Nusa Tenggara Barat merupakan salah satu provinsi di bagian timur Indonesia dengan basis kegiatan ekonomi utama adalah sumberdaya pertanian dan pertambangan. Kontribusi sektoral terhadap perekonomian Provinsi Nusa Tenggara Barat berdasarkan data BPS tahun 2017 didominasi oleh dua sektor utama yaitu pertanian, kehutanan, dan perikanan; dan pertambangan dan penggalian. Kontribusi dari kedua sektor ini masing-masing sebesar 21,33 persen dan 21,83 persen pada tahun 2016. Kondisi ini selaras dengan Rencana Tata Ruang Tata Wilayah (RTRW) Provinsi Nusa Tenggara Barat Tahun 2009-2029 yang mengatur fungsi wilayahnya sebagai kawasan unggulan agrobisnis. Proses pengembangan agrobisnis ini juga ditentukan dengan pelibatan sektor industri baik manufaktur maupun kreatif yang mendukung kegiatan pengolahan hasil-hasil pertanian.

Di sisi lain, kontribusi sektor indusrtri pertanian, kehutanan dan perikanan bila dilihat lebih rinci masih belum mencapai kondisi yang optimal. Berdasarkan data distribusi sumbangan sektor industri terhadap PDRB Provinsi Nusa Tenggara Barat dari tahun 2012 hingga tahun 2016, sektor pertanian, kehutanan dan perikanan terus mengalami penurunan walaupun tetap tinggi dibanding sektor lain. Hal ini berbeda dengan sektor pertambangan dan penggalian yang mengalami penurunan dari tahun 2012 namun berhasil bangkit di tahun 2015. Kondisi ini menjadi salah satu indikator bahwa untuk mencapai tujuan sesuai dengan RTRW Provinsi Nusa Tenggara Barat masih dibutuhkan usaha yang lebih pada sektor pertanian, kehutanan, dan perikanan. 
Kondisi lain yang perlu menjadi perhatian adalah belum meratanya pengembangan pada sektor industri lainnya. Dengan demikian analisis terhadap sumberdaya wilayah Provinsi Nusa Tenggara Barat diharapkan dapat memperkuat struktur industri yang memiliki kekuatan internal, keunggulan eksternal dan sistem yang sehat sehingga berkemampuan menciptakan pemerataaan. Mengetahui keunggulan sumberdaya wilayah untuk pembangunan industri akan memunculkan sektor dan komoditi unggulan yang berguna untuk meningkatkan daya saing industri di tingkat regional, nasional maupun global.

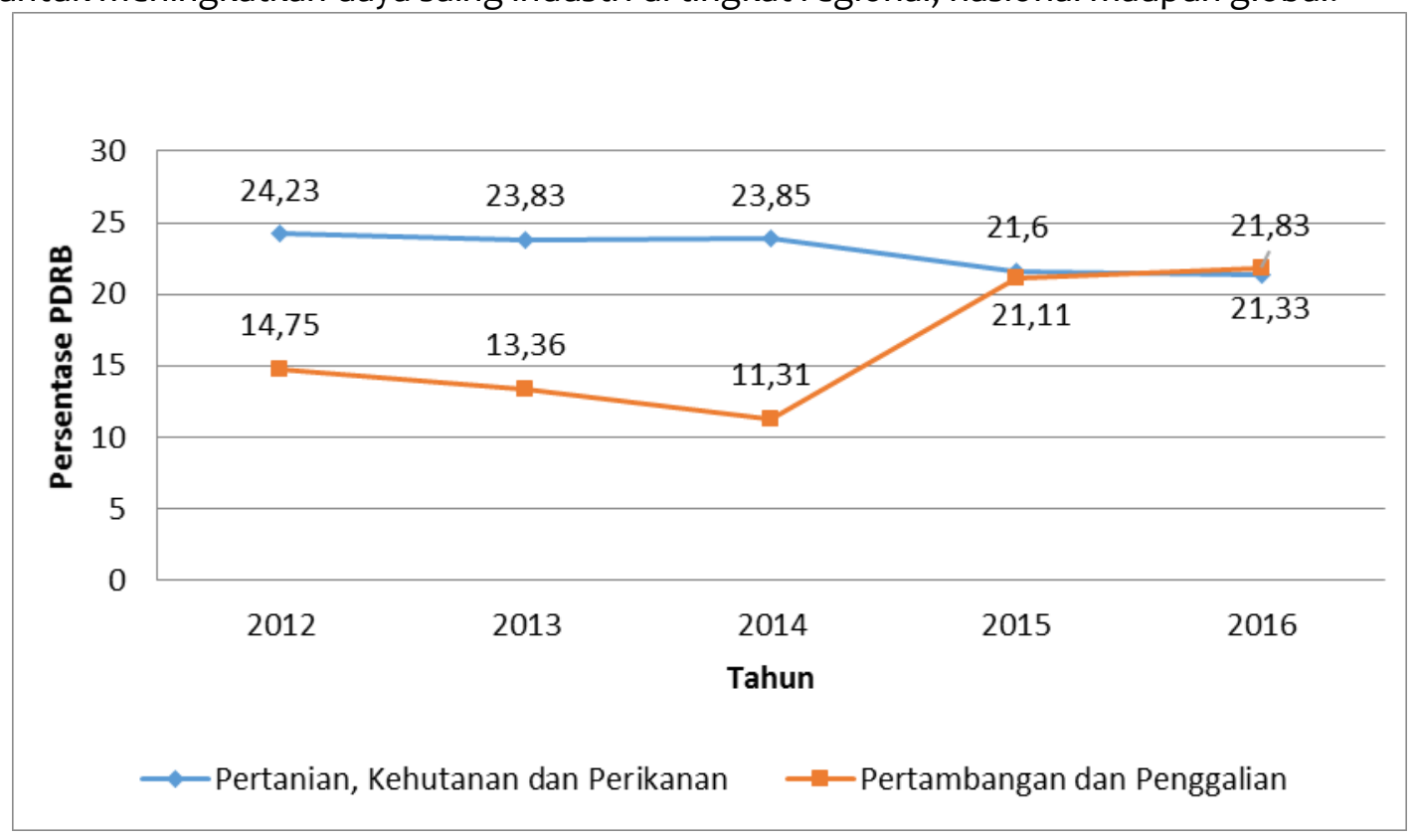

Sumber : Analisis Data Provinsi Nusa Tenggara Barat Dalam Angka Tahun 2012-2016

Gambar 1. Kontribusi sektoral terhadap PDRB Provinsi Nusa Tenggara Barat pada Dua Sektor Ekonomi Tertinggi

Sumberdaya wilayah memiliki peran penting dalam analisis untuk pengembangan industri. Sumberdaya didefinisikan sebagai aset yang dimanfaatkan untuk pemenuhan kebutuhan manusia untuk mencapai tingkat kepuasan tertentu (Grima dan Berkes, 1989). Pada suatu industri, sumberdaya digunakan sebagai bahan dasar untuk kemudian diolah lebih lanjut menjadi barang setengah jadi dan barang jadi. Suatu aset dapat dikatakan sebagai sumberdaya apabila memenuhi dua kriteria yaitu adanya pengetahuan, keterampilan dan tekonologi untuk memanfaatkan, dan ada permintaan terhadap sumberdaya tersebut (Rees, 1990).

Sumberdaya terdiri dari beberapa jenis yaitu sumberdaya alam, sumberdaya manusia dan sumberdaya lainnya yang menjad satu dalam sumberdaya wilayah. Sumberdaya alam merupakan input dalam pengembangan ekonomi yang penting (Saum, 2018) dan membentuk kesejahteraan manusia, lingkuungan dan ekonomi (IRP, 2017). Konsep ini selaras dengan konsep industri dari sudut pandang geografi yang merupakan sebuah sistem gabungan atas sub sistem fisik dan sub sistem manusia (Sumaatmaja, 1981). Sub sistem fisik pada industri sebanding dengan sumberdaya alam dan sub sistem manusia sebanding dengan sumberdaya manusia. Berdasarkan hal ini maka analisis terhadap sumberdaya wilayah Provinsi Nusa Tenggara Barat mengambil peran penting terhadap pengembangan industri di wilayah tersebut. 


\section{DATA DAN METODE}

\subsection{Indikator, Variabel dan Jenis Data}

Data yang digunakan dalam penelitian ini terbagi dalam bentuk data spasial dan data non spasial. Data spasial meliputi data yang berbasis peta yaitu peta dasar (Peta RBI) dan peta-peta tematik (Peta Rencana Pola dan Struktur Ruang Wilayah Provinsi/Kabupaten/Kota, Peta Sebaran Komoditas Unggulan dan Peta Sebaran Potensi Industri). Sedangkan data non spasial meliputi data yang berbasis produk kebijakan (Peraturan Perundangan baik tingkat Pusat maupun Daerah, RPJP Provinsi/Kabupaten/Kota, RPJM Provinsi/Kabupaten/Kota dan Kebijakan Sektoral Terkait) serta data statistik. Secara ringkas, data yang digunakan dalam penelitian ini disajikan dalam tabel berikut :

Tabel 1. Indikator, Variabel dan Jenis Data yang digunakan dalam Penelitian

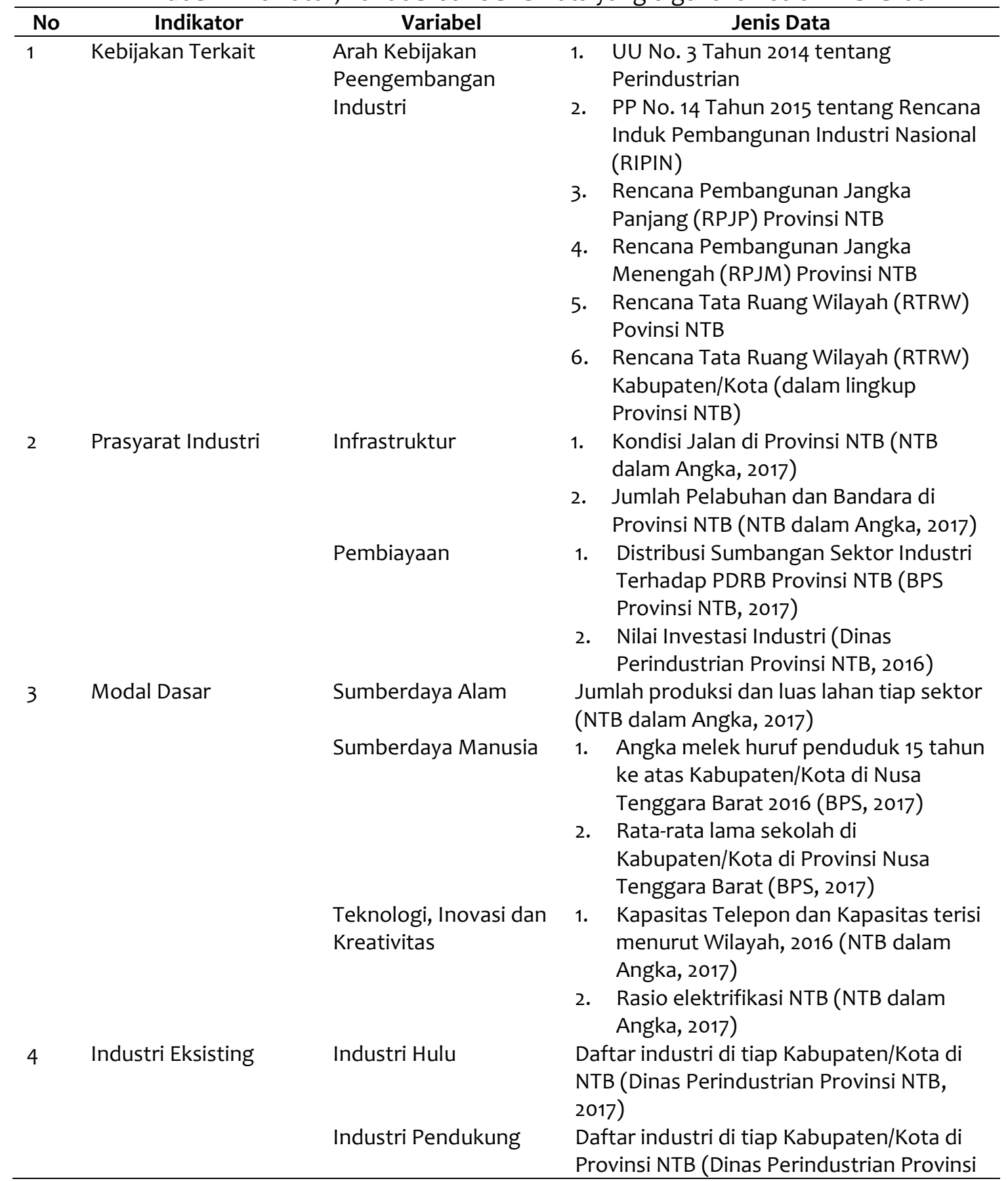


Purwohandoyo, Lubis, Pambudi, Wicaksono/ Jurnal Pembangunan Wilayah dan Kota, Vol.15, No.2, 2019, 275-287 Doi: https://doi.org/10.14710/pwk.v15i4.21732

\begin{tabular}{lll}
\hline No Indikator & \multicolumn{1}{c}{ Variabel } & \multicolumn{1}{c}{ Jenis Data } \\
\hline & NTB, 2017) \\
& Industri Andalan & Daftar industri di tiap Kabupaten/Kota di \\
& NTB (Dinas Perindustrian Provinsi NTB, \\
& $2017)$ \\
\hline
\end{tabular}

Sumber; Analisis, 2018

\subsection{Metode}

Metode analisis yang digunakan penelitian ini terdiri dari analisis Location Quotient (LQ) dan analisis kesenjangan. Analisis LQ merupakan proses membandingan perananan suatu kegiatan ekonomi dan atau industri dengan peranan sejenis pada tingkatan lebih tinggi dan bertujuan untuk mengukur tingkat konsentrasi kegiatan ekonomi dan atau industri pada daerah tertentu (McCann, 2001). Analisis LQ digunakan untuk melihat konsentrasi sumberdaya wilayah yang ada di Provinsi Nusa Tenggara Barat. Hasil dari analisis LQ dapat digunakan sebagai acuan penentuan industri yang akan dikembangkan pada daerah terkonsentrasi dan sekitarnya.

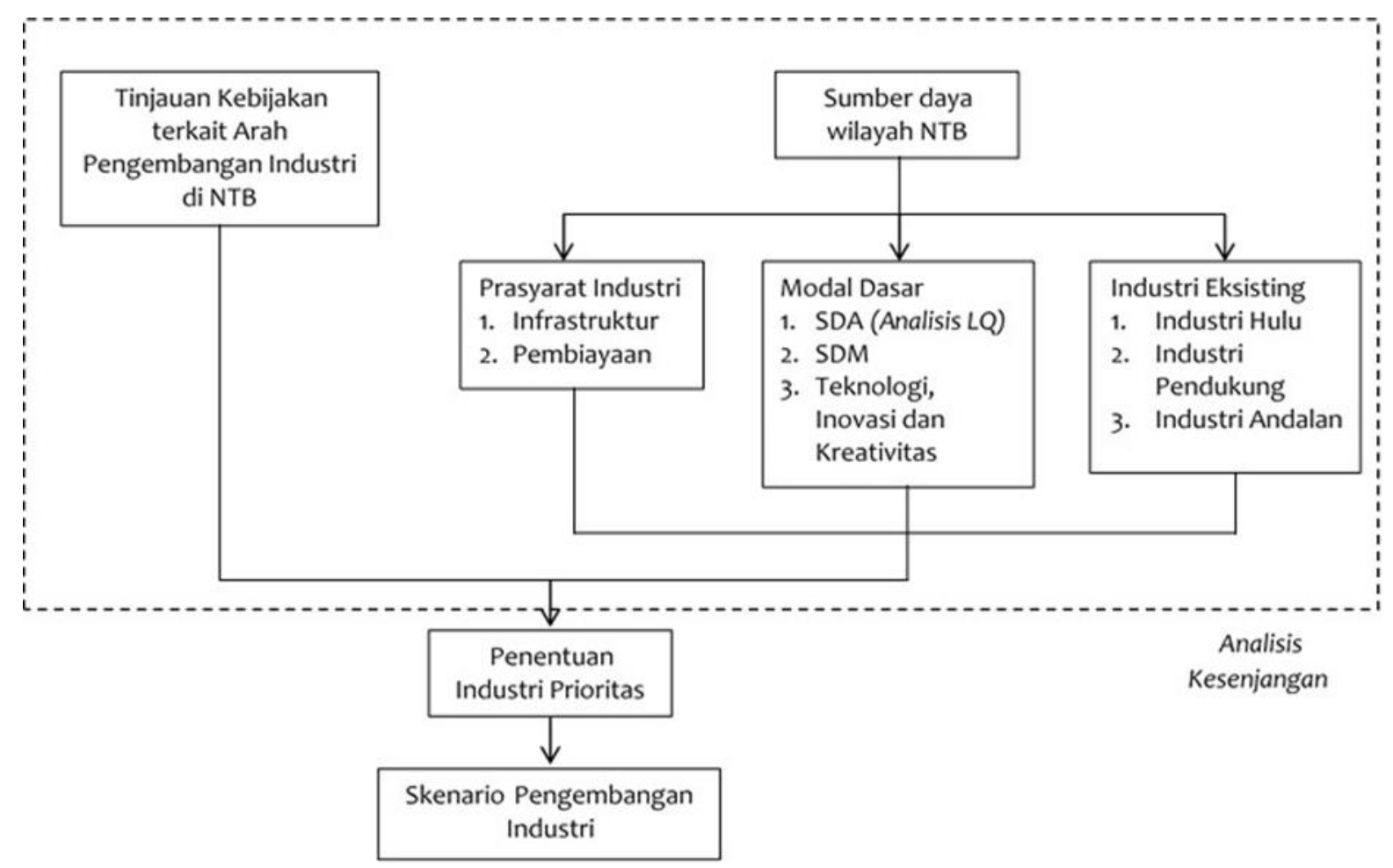

Sumber : Analisis, 2018

Gambar 2. Diagram Alir Proses Analisis Penelitian

Analisis berikutnya adalah analisis kesenjangan kebijakan yang menurut Dongol dan Heninen (2012), merupakan konsep yang membandingkan antara kebijakan dengan kenyataan. Analisis kesenjangan bertujuan untuk melihat kesenjangan antara kebijakan yang dikeluarkan oleh pemerintah dan ketersediaan sumberdaya wilayah. Ketersediaan sumberdaya wilayah menggunakan data hasil analisis LQ. Adapun komponen dalam analisis kesenjangan meliputi prasyarat industri, modal dasar dan industri eksisting. Kebijakan terkait pengembangan industri menjadi bagian dari prasyarat industri termasuk infrastruktur yang tersedia. Sesuai dengan Rencana Induk Pembangunan Industri Nasional bahwa prasyarat merupakan kondisi ideal yang dibutuhkan untuk memenuhi tujuan dari pembangunan industri. Adanya prasyarat 
industri juga didukung dengan tersedianya modal dasar yang terdiri dari sumberdaya alam dan sumberdaya manusia. Pengembangan industri juga perlu melihat industri yang telah tersedia karena tidak dapat sertamerta dihilangkan dan merupakan kondisi akutual dari wilayah tersebut. Berdasarkan pertimbangan berbagai komponen ini, kemudian dijadikan sebagai landasan penentuan sektor unggulan industri yang akan dikembangkan di Provinsi Nusa Tenggara Barat dan strategi pengembangan industrinya. Secara singkat, proses analisis yang dilakukan dalam penelitian dapat dilihat pada gambar 2.

\section{HASIL DAN PEMBAHASAN}

\subsection{Sebaran Potensi Sumberdaya Wilayah}

Pengembangan industri menjadi efektif ketika sektor dan jenis industri yang ditetapkan sesuai dengan ketersediaan sumber daya wilayah yang mendukung. Sumber daya dalam analisis ini adalah prasyarat industri dan modal dasar. Modal dasar merupakan sumber daya yang akan menjadi bahan baku utama dalam pengembangan industri. Sumber daya ini terdiri dari sumber daya alam yang telah tersedia di Nusa Tenggara Barat, yang tersebar di seluruh kabupaten/kota yang ada di Provinsi Nusa Tenggara Barat. Dari hasil analisis data, diperoleh berbagai komoditi yang menjadi unggulan seperti terlihat pada gambar 2.

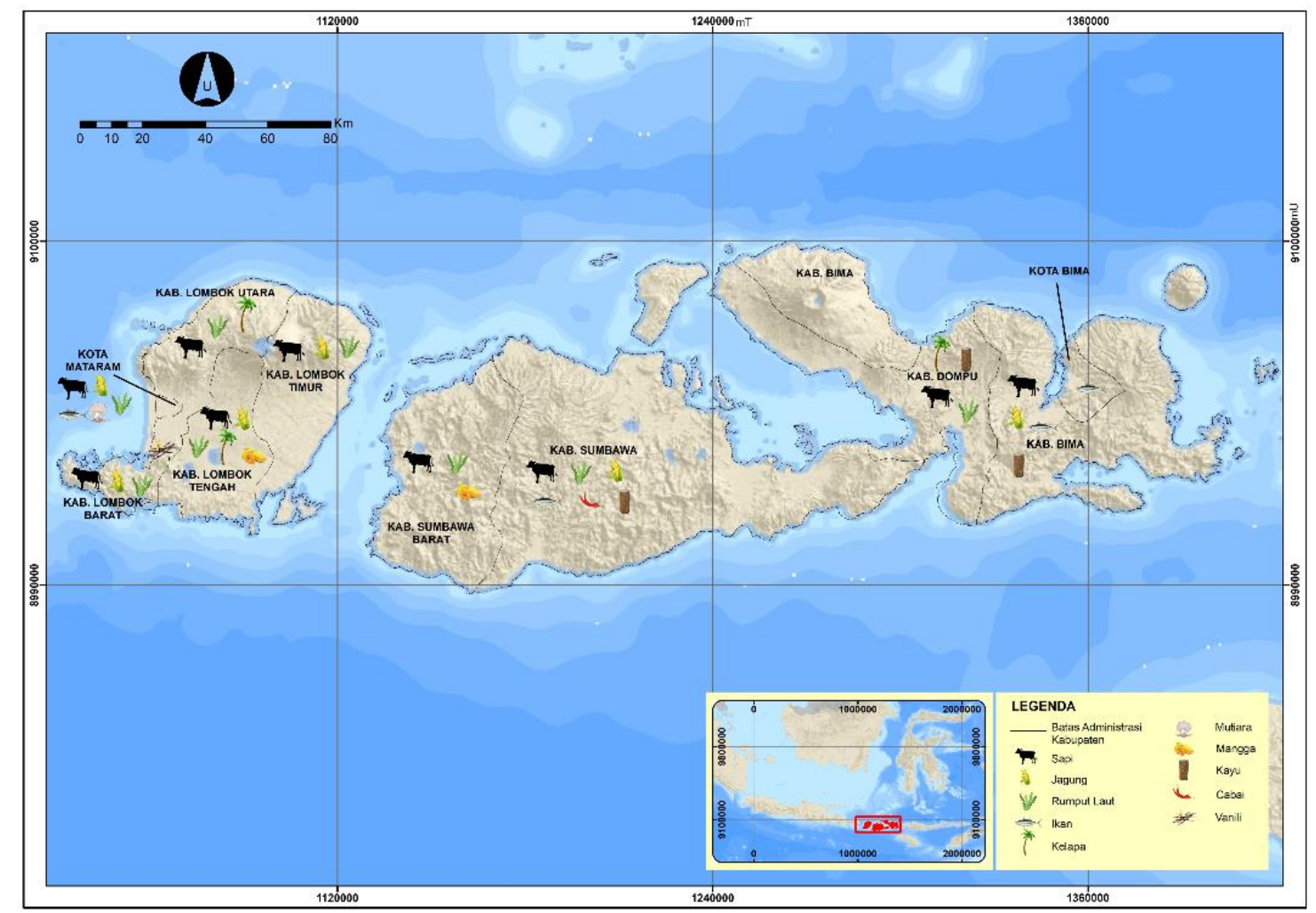

Sumber : Analisis, 2018

Gambar 3. Peta Sebaran Potensi Unggulan Sumber Daya Wilayah di Provinsi Nusa Tenggara Barat

Potensi sumberdaya alam yang tersebar di Provinsi Nusa Tenggara Barat terdiri dari beberapa sektor yaitu pertanian, hortikultura, buah-buahan, perkebunan, peternakan, perikanan dan kehutanan. Setiap daerah memiliki dominasi komoditas sumber daya alam yang berbeda-beda. Namun terdapat beberapa komoditi yang tersebar di beberapa daerah dan menjadi komoditi unggulan yang berpotensi untuk dikembangkan menjadi bahan baku industri di Provinsi Nusa Tenggara Barat.

Sektor pertanian memiliki potensi pengembangan komoditas jagung yang tersebar di Pulau Lombok dan Pulau Sumbawa. Jagung menjadi potensi tidak hanya dari persebaran komoditas yang merata 
di kedua pulau, faktor lain adalah kesesuaian jagung dengan iklim dan jenis tanah di wilayah ini sebagai salah satu faktor pendukung pengembangan komoditas ini. Lahan yang terdapat di Provinsi Nusa Tenggara Barat $84 \%$ dari luas lahan keseluruhan merupakan lahan kering yang sangat sesuai untuk pengembangan jagung.

Lahan kering yang terdapat di Provinsi Nusa Tenggara Barat juga menjadi sumber potensi pengembangan sumber daya yang lain seperti kelapa dan cabai. Kedua jenis tumbuhan ini dapat dikembangkan pada lahan kering sesuai dengan ketersediaan lahan yang ada di Provinsi Nusa Tenggara Barat. Saat ini, potensi dari komoditas cabai masih terpusat di Kabupaten Sumbawa dengan produksi tertinggi. Namun, komoditas ini masih sangat mungkin untuk dikembangkan di daerah lain mengingat ketersediaan lahan yang masih cukup memadai. Sedangkan untuk komoditas kelapa terdapat di Kabupaten Lombok Utara, Lombok Tengah dan Dompu.

Potensi sumberdaya terbesar yang ada di Provinsi Nusa Tenggara Barat ada pada sektor peternakan dan perikanan dengan komoditas unggulan sapi, ikan dan rumput laut. Ketiga jenis komoditas ini ada di setiap kabupaten/kota di Provinsi Nusa Tenggara Barat. Masyarakat NTB memiliki budaya yang mendukung pengembangan komoditi ini. Beternak sapi terutama bagi masyarakat di Pulau Sumbawa merupakan tradisi turun temurun yang terus dilestarikan. Beternak tidak hanya sekedar untuk dikonsumsi secara pribadi, melainkan juga untuk diperjualbelikan antar pulau. Provinsi Nusa Tenggara Barat memiliki garis pantai sepanjang $2.333 \mathrm{Km}$. Sepanjang garis pantai tersebut terdapat masyarakat yang menggantungkan kehidupannya pada hasil laut seperti ikan dan rumput laut. Penghasil ikan dan rumput laut di NTB tersebar di setiap kabupaten/kota sehingga menjadi komoditi yang cukup potensial untuk dikembangkan.

Potensi sumberdaya wilayah tidak hanya berdasarkan sumberdaya alam yang tersedia melainkan harus dipenuhi dengan adanya dukungan dari sumberdaya manusia. Penilaian potensi sumberdaya manusia yang ada di Provinsi Nusa Tenggara Barat dilihat dari angka Indeks Pembangunan Manusia (IPM) dan rata-rata lama studi (RLS) dibandingkan dengan sumbangan pertanian. Berdasarkan indikator ini, secara keseluruhan Kabupaten/Kota di NTB masih memiliki nilai sumberdaya manusia yang rendah. Kabupaten/Kota dapat dikelompokkan berdasarkan kualitas SDM yang tinggi, memiliki sumbangan sektor pertanian yang tinggi namun rata-rata lama sekolah rendah menjadi sentra hulu industri pertanian seperti Kabupaten Lombok Timur, Lombok Barat, Lombok Tengah, dan Lombok Utara. Perlu dilakukan strategi pembangunan SDM seperti penyediaan sarana belajar di keempat kabupaten tersebut agar dapat meningkatkan kualitas SDM-nya. Kabupaten Dompu, Sumbawa, dan Bima menjadi tiga kabupaten yang memiliki struktur industri pertanian yang besar dan RLS tinggi sehingga proses pengembangan menuju agro industri tidak terlalu sulit dikarenakan SDM yang sudah tersedia.

\subsection{Analisis Prioritas Industri Unggulan}

Penentuan sektor unggulan melihat keselarasan antar komponen yang mendukung. Hasil dari data dan analisis menunjukan masih adanya kesenjangan antara kebijakan, modal dasar dan industri yang tersedia di Provinsi Nusa Tenggara Barat. Kesenjangan ini terlihat dari perbedaan komoditi yang menjadi prioritas atau unggulan pada setiap komponen. Adanya kesenjangan dapat dipengaruhi oleh beberapa faktor tergantung pada setiap komponen yang dibandingkan. Perbandingan antar komponen dapat dilihat pada tabel 2.

Kesenjangan terlihat antara prasyarat industri dan modal dasar yang merupakan potensi yang terdapat di Provinsi Nusa Tenggara Barat. Setiap pemerintahan memiliki kewajiban untuk membuat kebijakan yang mendukung kegiatan di dalam daerahnya dan mengguntungkan bagi masyarakat. Kebijakan pemerintah seharusnya dibuat menyesuaikan dengan kondisi di lapangan dan harapan pengembangan di masa mendatang. Hal yang serupa juga berlaku pada kebijakan pengembangan sektor industri. Provinsi Nusa Tenggara Barat telah mengeluarkan serangkaian kebijakan yang berkaitan dengan kegiatan industri diantaranya dimuat dalam : 
1. Peraturan Daerah Provinsi Nusa Tenggara Barat Nomor 3 Tahun 2010 tentang Rencana Tata Ruang Tata Wilayah Provinsi Nusa Tenggara Barat 2009-2029

2. Peraturan Menteri Perindustrian Nomor 100/M-IND/PER-8-2010 tentang Peta Panduan (road map) Pengembangan Industri Unggulan Provinsi Nusa Tenggara Barat

Kedua dokumen kebijakan ini digunakan untuk melihat relasi antara kebijakan pemerintah dan hasil analisis kesenjangan antara ketersediaan modal dasar dan industri yang sudah tersedia. Merujuk pada prasyarat industri, Provinsi Nusa Tenggara Barat telah memiliki cukup modal dasar untuk mengembangkan industri ke tahap selanjutnya. Provinsi Nusa Tenggara Barat yang berbentuk kepulauan akan menjadi masalah terkait transportasi barang apabila ada pengembangan sektor industri. Masalah ini dapat terselesaikan sementara dengan banyaknya pelabuhan yang dimiliki di tiap pulau. Pelabuhan ini dapat mendukung berbagai kegiatan industri mulai dari pelabuhan perikanan, hingga pelabuhan penyeberangan lintas provinsi dan kabupaten. Transportasi di Provinsi Nusa Tenggara Barat juga didukung dengan adanya tiga bandara dimana salah satu diantaranya telah berstatus bandara internasional. Lokasi dari tiga bandara ini ada di kedua pulau utama di Provinsi Nusa Tenggara Barat yaitu Pulau Lombok dan Pulau Sumbawa.

Tabel 2. Identifikasi faktor-faktor pendukung pengembangan industri di Provinsi NTB

\begin{tabular}{|c|c|c|c|}
\hline Prasyarat Industri & Modal Dasar & Industri Eksisting & Sektor Unggulan \\
\hline Infrastruktur: & SDA & 1. Industri Hulu : Furnitur & Ind. Hulu Agro: \\
\hline 1. $42,26 \%$ kondisi jalan baik & 1. Pertanian : Jagung & 2. Industri Pendukung : & 1. Jagung \\
\hline 2.20 Pelabuhan & 2. Hortikultura : Cabai besar & Pande besi & 2.Sapi \\
\hline 3.3 Bandara & 3. Buah-buahan: Mangga & 3. Industri pangan: & 3.Kelapa \\
\hline & 4. Perkebunan : Vanili, & Pengolahan tepung, & 4.Vanili \\
\hline Kebijakan: & tembakau, kelapa & Pengolahan perikanan. & 5.Tembakau Virginia \\
\hline Permen 100/M- & 5. Peternakan : Sapi & Garam & \\
\hline $\begin{array}{l}\text { IND/PER/8/2010 } \\
\text { Industri unggulan Provinsi: } \\
\text { 1. Jagung }\end{array}$ & $\begin{array}{l}\text { 6. Perikanan : Tiram mutiara, } \\
\text { rumput laut, budidaya air } \\
\text { payau }\end{array}$ & $\begin{array}{l}\text { 4. Industri elektronika: } \\
\text { Reparasi dan pemasangan } \\
\text { mesin dan peralatan }\end{array}$ & $\begin{array}{l}\text { Ind. Hulu: } \\
\text { Furnitur kayu }\end{array}$ \\
\hline 2. Sapi & 7. Kehutanan: kehutanan & 5. Industri Transportasi: & Industri Pendukung: \\
\hline $\begin{array}{l}\text { 3. Ikan dan rumput laut } \\
\text { 4. Kerajinan }\end{array}$ & kayu rimba & $\begin{array}{l}\text { Bengkel } \\
\text { 6. Industri tekstil dan aneka: }\end{array}$ & Pande besi \\
\hline & SDM & Tenun gedogan & Industri Pangan: \\
\hline RTRW NUSA TENGGARA & Hubungan antara IPM dan & & 1.Pengolahan hasil \\
\hline BARAT 2009-2029 & Sumbangan Pertanian: & & pertanian \\
\hline 1. Kawasan Industri & Kuadran IV (sumbangan & & 2.Pengolahan sapi \\
\hline $\begin{array}{l}\text { Masyarakat Perkebunan } \\
\text { (KIM-bun) } \\
\text { 2. Pengembangan Industri }\end{array}$ & $\begin{array}{l}\text { pertanian rendah - IPM } \\
\text { rendah) }\end{array}$ & & $\begin{array}{l}\text { 3.Pengolahan } \\
\text { perikanan dan rumput } \\
\text { laut }\end{array}$ \\
\hline Pengolahan Hasil & Hubungan antara rata-rata & & \\
\hline Ternak & $\begin{array}{l}\text { lama studi dan sumbangan } \\
\text { pertanian: }\end{array}$ & & $\begin{array}{l}\text { Ind. Tekstil dan aneka: } \\
\text { Tenun Gedogan }\end{array}$ \\
\hline & $\begin{array}{l}\text { Kuadran IV (subangan } \\
\text { pertanian rendah - RLS } \\
\text { rendah) }\end{array}$ & & \\
\hline
\end{tabular}

Sumber : Analisis, 2018

Apabila dilihat dari aspek kebijakan yang dikeluarkan oleh pemerintah, pengembangan industri di Provinsi Nusa Tenggara Barat dapat dilakukan dengan efektif. Hal ini dikarenakan, pemerintah setempat telah mengalokasikan kebijakan secara khusus untuk pengembangan industri dengan adanya peraturan secara khusus dari Kementerian Perindustrian dan RTRW Provinsi Nusa Tenggara Barat yang telah membahas secara khusus mengenai Kawasan Industri Masyarakat Perkebunan (KIM-bun). Industri yang disasar untuk dikembangkan oleh pemerintah Provinsi Nusa Tenggara Barat adalah argoindustri yang 
memanfaatkan modal dasar sumber daya alam yang terdapat di NTB. Argoindustri yang disasar untuk dibangun melalui industri unggulan provinsi adalah industri dari komoditi pertanian yaitu jagung, sapi, perikanan dan rumput laut. Industri ini juga ditambah dengan sektor kerajinan untuk meningkatkan dan memperkenalkan budaya lokal di NTB. Kebijakan yang tertuang dalam RTRW Provinsi Nusa Tenggara Barat mencoba mengembangkan industri dari sektor lain namun masih termasuk dalam pengembangan agroindustri yaitu perkebunan dan pengolahan hasil ternak.

Antara kebijakan pemerintah dan modal dasar industri, terdapat kesinambungan yang lebih baik. Kesenjangan diantara keduanya cukup rendah karena komoditi yang tercantum dalam kebijakan pemerintah sesuai dengan potensi sumber daya alam yang terdapat di Provinsi Nusa Tenggara Barat. Keselarasan diantara keduanya terlihat pada komoditi pertanian, yang mana pada modal dasar menjadi unggulan untuk pengembangan industri direspon positif oleh pemerintah dengan adanya kebijakan PIJARI (sapi, jagung, perikanan dan rumput laut, serta kerajinan) berdasarkan Permen No. 100/M-IND/8/2010. Kebijakan PIJARI menjadi dukungan nyata bahwa modal yang dimiliki dapat dibawa ke tingkat yang lebih lanjut yaitu pengelohan bahan baku. Industri pengolahan yang dapat dilakukan dengan kebijakan ini adalah pengolahan jagung, sapi, ikan dan rumput laut. Kebijakan lainnya yang selaras dengan modal dasar yang dimiliki adalah Kawasan Industri Masyarakat Perkebunan (KIM-BUN). Tidak semua komoditi yang diatur pemerintah tersedia pada hasil analisis modal dasar, akan tetapi terdapat beberapa yang sesuai yaitu komoditi kelapa, vanili dan tembakau.

Kesenjangan antara kebijakan dan modal dasar tidak terjadi pada industri yang saat ini sudah berjalan di Provinsi Nusa Tenggara Barat. Industri yang tersedia belum sepenuhnya sesuai dengan kebijakan pemerintah. Banyaknya industri yang sudah berjalan saat ini, berdasarkan hasil analisis LQ hanya terdapat pada 2 (dua) sektor yang sesuai dengan kebijakan yang dikeluarkan oleh pemerintah yaitu industri kerajinan dan pengolahan ikan. Sektor ini sesuai dengan kebijakan yang tertuang dalam Permen No. 100/MIND/9/2010, yang merupakan bagian dari komoditi PIJARI. Industri kerajinan sesuai dengan kebijakan karena industri ini telah berkembang sejak lama dan merupakan produk khas Nusa Tenggara Barat yaitu Tenun Gedogan. Kegiatan tenun telah menjadi aktivitas yang menyatu dengan kebudayaan dan keseharian masyarkat setempat. Hal yang serupa terjadi pula pada industri pengolahan ikan. Provinsi NTB dengan bentuk wilayah kepulauan membuat jumlah masyarakat pesisir yang tinggi hingga akhirnya kegiatan yang berhubungan dengan perikanan menjadi budaya dan kebiasaan sehari-hari.

Belum optimalnya kegiatan industri yang sesuai dengan kebijakan pemerintah dapat terjadi karena berbagai hal. Dalam analisis yang dilakukan, kemungkinan kesenjangan ini dikarenakan faktor sumber daya manusia. Berdasarkan analisis dengan indikator IPM dan rata-rata lama studi yang dihubungankan dengan sumbangan sektor pertanian, kedua indikator masih pada posisi yang lemah. Sehingga, dapat menjadi indikator bahwa kurangnya kemampuan masyarakat yang menjadi sebab kurangnya pengembangan industri yang sesuai dengan kebijakan pemeringah. Kemampuan masyarakat dalam pengembangan industri merupakan faktor penting karena masyarakat yang akhirnya akan mengelola bahan baku hingga akhirnya menjadi barang setengah jadi atau barang jadi. Kemampuan pengelolaan ini dimulai dari meningkatkan hasil panen komoditi, mengelola bahan baku menjadi barang setengah jadi, barang jadi, teknologi, pengemasan produk, penjualan dan pemasaran. Untuk meningkatkan kemampuan masyarakat, pemerintah perlu melakukan beberapa strategi diantaranya pelatihan untuk masyarakat serta pendampingan. Faktor lain yang dapat menjadi sebab kesenjangan adalah kurangnya modal yang dimiliki oleh masyarakat. Sehingga pemerintah juga perlu memberikan sarana peminjaman modal kepada masyarakat untuk mendukung kegiatan pengembangan industri.

Kesenjangan lain yang terjadi pada pengembangan industri di Provinsi Nusa Tenggara Barat adalah kesenjangan antara modal dasar dan industri yang telah tersedia. Modal dasar seharusnya menjadi acuan utama dalam pengembangan suatu kegiatan industri, karena dengan modal inilah kegiatan industri akan berjalan. Pada kenyataannya kegiatan industri yang berjalan belum sepenuhnya menggunakan sumber bahan baku pertanian, yang mana menjadi fokus pemerintah dan sebenarnya telah tersedia. Berdasarkan supply chain pada industri, modal dasar merupakan bahan baku utama sebelum akhirnya diolah menjadi barang jadi atau setengah jadi. 
Berdasarkan hasil analisis terlihat bahwa modal dasar yang terdapat di wilayah tersebut belum dimanfaatkan secara optimal. Industri yang ada cenderung memanfaatkan sumber daya lain di luar dari modal dasar yang sebenarnya unggul dan dapat dimanfaatkan secara lebih untuk kegiatan industri. Dari tujuh sektor sumber daya alam hanya dua sektor yang sudah dimanfaatkan sebagai bahan baku untuk industri eksisting yang cukup besar dan berkembanga di Nusa Tenggara Barat. Sektor sumber daya alam lainnya masih belum dimanfaatkan secara optimal sebagai bahan baku untuk industri. Rendahnya penggunaan sumber daya alam sebagai bahan baku untuk industri terlihat dari sumbangan sektor pertanian terhadap PDRB Provinsi Nusa Tenggara Barat. Semakin rendah sumbangan sektor pertanian berarti bahwa sektor tersebut belum dimanfaatkan secara optimal. Sektor pertanian masih dapat dikembangkan lebih lanjut untuk menjadi bahan baku utama pengembangan industri. Pengembangan yang masih mungkin untuk dilakukan adalah dengan membuka industri pengelolaan makanan dari hasil panen pertanian, perkebunan dan hortikultura.

\subsection{Skenario Pengembangan Industri}

Komoditi unggulan merupakan jenis industri yang akan diunggulkan dan mendapatkan prioritas dalam pengembangan. Landasan pemilihan komoditi unggulan berdasarkan tiga komponen yang telah dianalisis sebelumnya yaitu prasyarat industri, modal dasar dan industri yang telah tersedia. Komoditi unggulan dipilih berdasarkan komoditi yang memiliki keselarasan pada ketiga komponen tersebut. Berdasarkan hasil analisis tiga komponen utama dan sektor unggulan yang telah ditetapkan maka dapat ditentukan skenario pengembangan yang tepat untuk setiap komoditi unggulan. Skenario pengembangan ditentukan dengan melihat kekurangan yang ada pada setiap komponen untuk dikembangkan, dan mempertahankan serta berupaya untuk meningkatkan pada komponen yang sudah baik.

Provinsi Nusa Tenggara Barat memiliki kekayaan alam yang melimpah dan didukung dengan sumber daya manusia serta kebijakan yang dikeluarkan oleh pemerintahnya. Kondisi ini menjadi kesempatan yang sangat baik untuk mengembangkan industri tidak hanya sebatas kebijakan namun mengimplementasikan kebijakan tersebut. Berdasarkan hasil analisis kesesuaian antar komponen maka terdapat beberapa sektor unggulan untuk pengembangan industri di Provinsi Nusa Tenggara Barat. Setiap sektor unggulan dengan komoditi pertanian diturunkan sesuai dengan Klasifikasi Baku Lapangan Usaha Indonesia (KBLI, 2017) menjadi industri pangan. Industri pangan mencakup industri pengolahan hasil alam menjadi produk makanan setengah jadi dan makanan jadi, seperti industri pengolahan jagung, kelapa, vanili, sapi, perikanan dan rumput laut.

Sektor unggulan yang telah dipilih memerlukan strategi utama agar pengembangan industri dapat lebih efektif dan efisien. Terdapat lima strategi utama dalam pengembangan sektor unggulan yang diterapkan pada seluruh komoditi unggulan yaitu peningkatan produksi, pengembangan SDM, pengembangan dan pemanfaatan teknologi industri, pengembangan kreativitas dan inovasi serta penyediaan sumber pembiayaan. Lebih spesifik setiap kelompok industri terdapat strategi prioritas dengan tujuan agar pengembangan industri lebih fokus, efisien dan efektif. Pada kelompok industri hulu maka strategi prioritasnya adalah untuk meningkatkan produksi komoditi, dengan tujuan dapat menunjang proses industri pengolahan setelahnya. Pada industri pengolahan sendiri diprioritaskan untuk mengembangkan SDM yang akan bertindak sebagai penanggung jawab proses produksi, pemanfaatan teknologi, serta pengembangan kreativitas dan inovasi.

Pengembangan industri di Provinsi Nusa Tenggara Barat dibagi menjadi dua yaitu industri hulu dan industri hilir. Hal ini berlaku untuk pengembangan agroindustri dan industri kerajinan.

Untuk agro industri pada industri hulu bertujuan untuk meningkatkan hasil komoditi yang diunggulkan agar dapat memenuhi kriteria minimum sebagai bahan baku industri. Peningkatan produksi pertanian dan perkebunan dilakukan dengan mengembangkan perbenihan dan pupuk. Kedua hal ini mengambil peran penting pada industri hulu. Optimalisasi pada kedua sektor ini akan mempengaruhi kualitas dan kuantitas bahan baku yang dihasilkan. 
Industri hilir dari agro industri fokus kepada pengolahan bahan baku agar dapat memberikan nilai tambah dan menjadi barang jadi siap untuk dijual. Pengembangan industri hilir didukung penuh dengan pengembangan industri kreatif yang berarti di setiap kegiatan dan unit fokus kepada inovasi dan kreativitas pelaku industri. Kegiatan yang dapat dilakukan untuk pengembangan agro industri adalah pelatihan SDM sehingga meningkatkan keahlian mengelola dan meningkatkan kreativitas. Untuk menunjang kemampuan SDM maka perlu diberikan teknologi yang memadai untuk menunjang kegiatan pengolahan bahan baku.

Produk olahan dibagi menjadi dua yaitu produk olahan umum dan produk olahan khusus. Kedua produk ini ditujukan untuk menjangkau dua pasar yang berbeda. Produk olahan umum menghasilkan produk standar yang sering ditemui di pasar atau produk dengan permintaan yang tinggi karena merupakan produk harian masyarakat. Produk ini ditujukan untuk pasar lokal atau masyarakat Provinsi Nusa Tenggara Barat. Produk olahan khusus merupakan produk inovasi yang ditujukan kepada wisatawan yang datang ke Provinsi Nusa Tenggara Barat. Produk yang dihasilkan merupakan produk khas yang hanya dapat ditemui di Provinsi Nusa Tenggara Barat. Adanya produk ini dimaksudkan untuk mendukung program pemerintah terkait wisata halal di Provinsi Nusa Tenggara Barat, sehingga setiap produk hasil olahan UKM dapat menjadi produk "oleh-oleh" yang telah terjamin kebersihan, kelayakan dan halal untuk dikonsumsi.

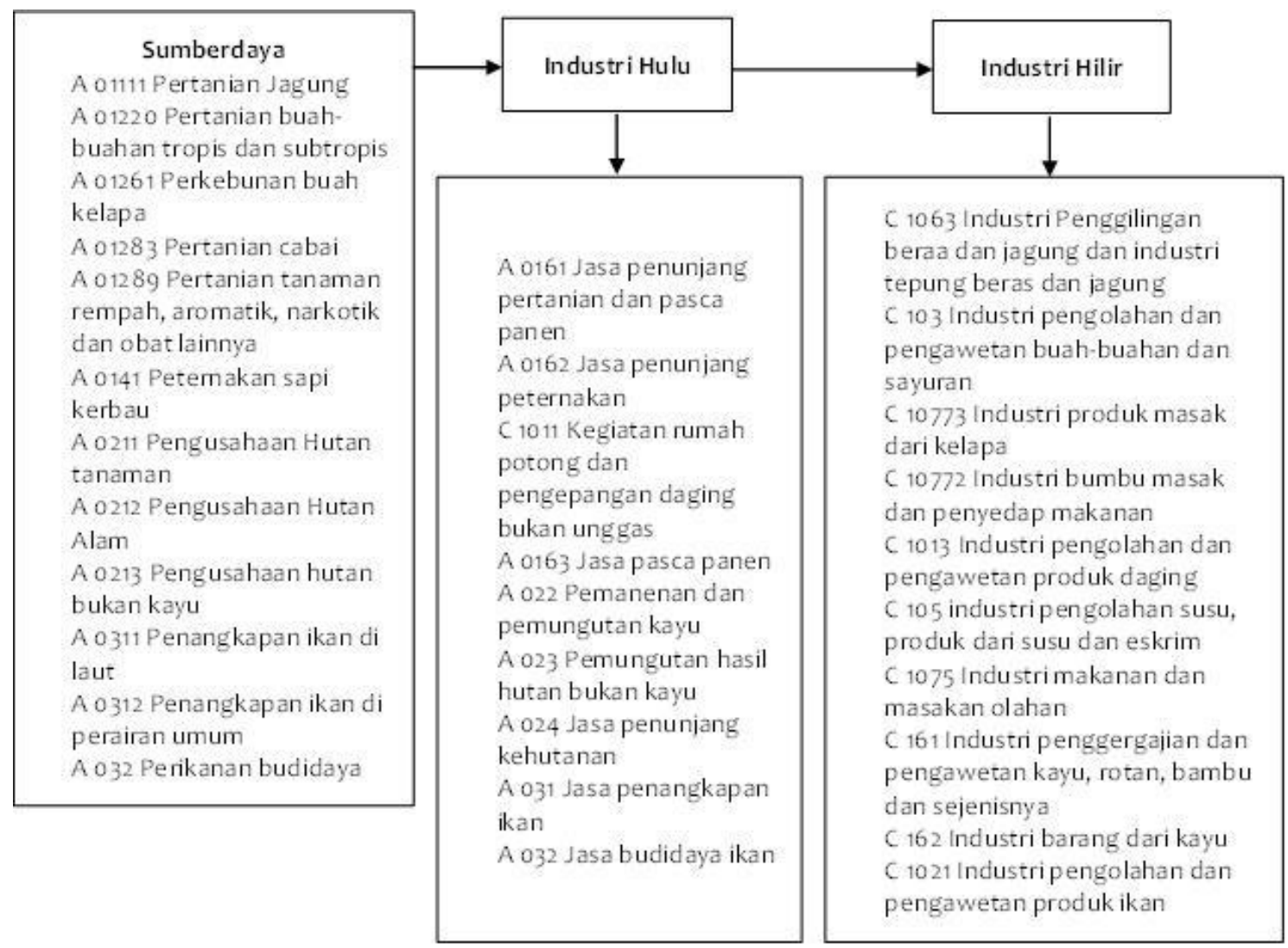

Sumber : Analisis, 2018

Gambar 4. Skema Alur Pengembangan Sumberdaya Wilayah Unggulan untuk Pengembangan Industri berdasarkan KBLI di Provinsi Nusa Tenggara Barat

Berdasarkan sumber daya alam unggulan di Provinsi Nusa Tenggara Barat terdapat beberapa produk olahan pertanian, perkebunan, peternakan serta perikanan yang dapat dihasilkan. Produk olahan 
sektor pertanian dengan bahan baku jagung dapat menghasilkan produk olahan umum seperti tepung jagung, gula jagung dan produk olahan khusus berupa mie jagung dan es krim jagung. Produk olahan umum vanili adalah bubuk vanili untuk perasa makanan, dan produk olahan khusus vanili akan dikembangkan pada industri ekstrak vanili yang akan digunakan sebagai parfum. Produk olahan umum kelapa adalah kecap dan minyak kelapa sedangkan produk olahan khusus dari kelapa adalah nata de coco dengan varian rasa hasil pengolahan industri kreatif.

Sektor peternakan dan perikanan di Provinsi Nusa Tenggara Barat meiliki tiga sumber daya unggulan yaitu sapi, ikan dan rumput laut. Produk hasil olahan sapi dapat digunakan sebagai produk olahan umum dan produk olahan khusus, yang mana produknya adalah susu, dendeng dan abon sapi. Abon juga dapat menjadi produk olahan khusus dari Provinsi Nusa Tenggara Barat dengan bahan baku yang berbeda yaitu ikan. Produk olahan lainnya menggunakan rumput laut sebagai bahan baku yang mana produk yang dapat dihasilkan adalah keripik rumput laut dan dodol rumput laut yang dapat dijadikan sebagai oleh-oleh khas Provinsi Nusa Tenggara Barat. Selain itu, industri hilir juga termasuk pada proses pengemasan, penjualan, dan pemasaran dari produk. Untuk mencapai tujuan maka diperlukan pula kerjasama dari berbagai pihak baik masyarakat sebagai pelaku industri, pemerintah dan pihak swasta juga turut berperan sebagai fasilitator.

Industri kerajian menghasilkan produk-produk yang khas sesuai dengan daerahnya sehingga dapat membentuk segmen pasar tertentu yang minim dengan persaingan. Supply industri kerajinan berawal dari pemasok bahan baku menyesuaikan dengan produk kerjainan yang akan dihasilkan. Pemasok bahan baku juga termasuk dari penyedia bahan pendukung, penolong dan permesinan. Dari rantai input bahan baku dan lainnya di-supply ke produsen untuk diolah menjadi produk jadi dan setengah jadi sesuai dengan produk kerajinan yang dibuat. Dari produsen produk masuk ke penjual hingga akhirnya produk sampai di konsumen.

Dari berbagai uraian di atas terlihat bahwa sumberdaya wilayah baik yang bersifat alamiah maupun buatan manusia, memiliki potensi yang tinggi untuk dikembangkan melalui sektor industri. Hal ini tentu saja perlu didukung dengan sumber daya manusia, teknologi dan permodalan atau investasi yang memadai. Kesemua hal tersebut juga perlu dikombinasikan dengan aspek kreativitas dan inovasi agar supaya produk atau hasil industri dapat bersaing pada berbagai level atau skala. Dengan demikian nilai tambah secara ekonomi akan dapat ditingkatkan dan akan semakin mendorong perkembangan perekonomian pada wilayah tersebut.

\section{KESIMPULAN}

Sumberdaya wilayah yang terdapat di Provinsi Nusa Tenggara Barat terdiri dari bebagai jenis. Ketersediaan sumberdaya wilayah didukung dengan kebijakan pemerintah membuat pengembangan industri semakin efektif. Berdasarkan analisis yang telah dilakukan maka, industri yang sebaiknya di kembangkan di Provinsi Nusa Tenggara Barat adalah agroindustri dan industri kerajinan tenun gedogan. Kedua jenis sumberdaya ini memiliki potensi yang tinggi di Provinsi NTB serta sudah sedemikian dikenal oleh masyarakat setempat.

\section{PERNYATAAN RESMI}

Tulisan ini merupakan bagian dari hasil laporan kerjasama yang dilakukan dengan Dinas Perindustrian Provinsi Nusa Tenggara Barat dimana kesemua penulis terlibat aktif dalam proses penulisan. Penulis berterima kasih kepada pihak terkait yang telah memberikan kesempatan. Isi dari tulisan ini hanya mengambil satu sudut pandang dari hasil pekerjaan secara utuh, yang penulis rasa paling penting dan menjadi prioritas. 


\section{REFERENSI}

Badan Pusat Statistik. (2017). Peraturan Kepala Badan Pusat Statistik Nomor 19 Tahun 2017 tentang Perubahan Atas Peraturan Kepala Badan Pusat Statistik Nomor 95 tahun 2015 tentang Klasifikasi Baku Lapangan Usaha Indonesia. Jakarta.

Dongol, Y., Heinen., J.T. (2012). Pitfall of CITES implementation in Nepal: a policy gap analysis. Environ, Manage. 50. 181-190.

Dumairy. (1996). Perekonomian Indonesia. Jakarta: Penerbit Erlangga.

Grima, A.P.L dan F. Berkes. (1989). Natural Resources: Acces, Right to Use and Management in Berkes. F. (ed) Common Property Resources: Ecology and Community based Sustainable Development. London: Belhaven Press.

IRP. (2017). Assessing Global Resource Use: A Systems Approach to Resource Efficiency and Pollution Reduction. International Resource Panel, United Nations Environment Programme.

Kartasapoetra. (2000). Makro Ekonomi. Jakarta: Raja Grafindo.

McCann, P. (2001). Urban and Regional Economics. London: Oxford University Press.

Nawawi, I., Ruyadi, Y., Komariah, S. (2015). Pengaruh Keberadaan Industri terhadap Kondisi Sosial Ekonomi dan Budaya Masyarakat Desa Lagadar Kecamatan Marga Asih Kabupaten Bandung. Jurnal Sosietas,Vol 5, No. 2.

Rees, J. (1990). Natural Resurces: Allocation, Economics and Policy. London and New York: Rout Ledge.

Republik Indonesia. (2014). Undang-Undang Nomor 3 Tahun 2014 tentang Perindustrian. Jakarta.

Saum, A.M., Baldi, M.G., Gunderson, I., Oberle, B. (2018). Articulating Natural Resources and Sustainable Development Goals through Green Economy Indicators: A Systematic Analysis. Resources, Conservation and Recycling. Vol 139, Dec 2018, p.90-103.

Scott, A.J. (2000). The Cultural Economy of Cities. London: Sage.

Singgih, M., Hennytasari, E. (2009). Pemilihan Alternatif Perbaikan Kinerja Lingkungan Sektor Industri Potensial di Jawa Timur dengan Metode Economic Input-Output Life-Cycle Assessment (EIO-LCA) dan Analytic Network Process (ANP). Seminar Nasional Perencanaan Wilayah dan Kota ITS, Surabaya. 29 Oktober 2009.

Sumaatmaja. (1981). Studi Geografi Suatu Pendekatan dan Analisa Keruangan. Bandung: Alumni.

Wulandari, E. D. (2007). Analisis Biaya Manfaat Pengelolaan Lingkungan Sentra Industri Kecil Tahu Jomblang Kota Semarang. Tugas Akhir Jurusan PWK, Universitas Diponegoro, Semarang. 